\title{
Everyday Aesthetics in Indian Cultural Communities
}

\author{
Tapaswi H M \\ Assistant Professor, Dr. NSA Memorial First Grade College, Nitte, Karkala Taluk, Udupi \\ District, 574110, tapaswi.hm@gmail.com, oooo-0oo2-6867-6o88.
}

\begin{abstract}
In India the concept of "folk culture", "folk literature", "folk art form" and other forms of many indigenous folk cultures seem to be considered not aesthetic but quaint, due to the dominance of "classical" art forms which are valued more. One can witness the dearth of qualitative understanding of the experience of beauty in these actions and objects which are not considered as art objects or artistic performances in Indian context. A theoretical perspective which tries to understand these genres and even ritual forms is also rare. In the contemporary academics, many scholars both from the Indian tradition and non-Indian traditions are attempting to understand a different kind of aesthetics that the art forms of these people express. Thus, in this paper, I claim that understanding indigenous art is possible using theories of everyday aesthetics rather than through other special theories of aesthetics. While not arguing for a relative view of aesthetics, this paper uses the ideas of everyday aesthetics and beauty to understand art in folk and cultural contexts in India.
\end{abstract}

Keywords: Everyday Aesthetics, Symbolic Meaning, Rangoli, imagination, beauty

\section{Introduction}

In India Rangoli is a very culture specific drawing art form that is drawn in front of the house every day. The experience of a drawn Rangoli can be perceived in two ways - aesthetic experience and symbolic experience. If the person born and brought up in the community where she has been witnessing the pattern, shape, and the meaning behind drawing a Rangoli, then she can certainly get the symbolic experience from the Rangoli. If the same person doesn't know anything about Rangoli, then she may experience aesthetic rapture that may be divorced from its embeddedness in culture. It is possible that the pattern may set off an element of novelty as well as strangeness that may not even be understood as aesthetically oriented. In both these cases the preliminary steps seem to be common, which I discussed in the forthcoming sections.

To start with a hypothesis, both kinds of experience seemingly provide a platform to judge the beauty of the object. This judgement may differ from one experience to another or one experiencer to another depending upon the degree of experience or the community in which the person born and brought up. For example, a person may use her prior knowledge of Rangoli, its pattern, its color, its cultural significance, and its meaning and so on to judge whether the drawing of Rangoli is beautiful or not. This kind of judgement of beauty is dependent upon the person's indigenous experience of Rangoli, it could almost be said to be a part of a cultural language of symbols. At the same time, a person, who doesn't know about the background of the Rangoli, can still imagine many dimensions of the drawing of Rangoli and can also judge the beauty based on the harmonious interplay between two of her faculties of mind - imagination and

(c) AesthetixMS 2019. This Open Access article is published under a Creative Commons Attribution Non-Commercial 4.0 International License (http://creativecommons.org/licenses/by-nc/4.o/), which permits non-commercial re-use, distribution, and reproduction in any medium, provided the original work is properly cited. For citation use the DOI. For commercial re-use, please contact editor@rupkatha.com. 
understanding. In both the cases, the experience plays a paramount role to initiate the process of judgment.

The act of positioning the judgment after the experience may seem to problematic for many scholars. But in Indian tradition, both these processes - judgment and experience - are somehow intermingled. Therefore, in this article, I examine the difference between the nature of aesthetic experience and what I refer to as the culturally embedded indigenous experience using concepts from Indian traditions of thought.

\section{Concept of Beauty in Indian Traditions of Thought}

The study of the concept of beauty in traditions of thought such as those in premodern India which consider it an experience must begin with a careful consideration of the terms that refer to the concept in literature, particularly in Sanskrit. In Indian traditions, the text Amarakośa $a^{i i}$ of Amarasimha is a good reference for synonyms for the term beauty in Sanskrit, which are as follows:

sundaram ruciram cāru suṣamaṃ sādhu śobhanaṃ|

kāntam manoramaṃ rucyaṃ manojňam maňju maňjulaṃ || 52 ||

(Amarasimha, 2013, p. 367).

Apte (1890) defines sundaram as lovely, ruciram as tasteful, sweet, palatable, cāru as agreeable, pleasing, sādhu as good, virtuous, pleasing, śobhanam as handsome, shining, beauty kāntam as desired, pleasing, lovely, rucyam as bright, maňju and maňjulam also as lovely. ${ }^{\text {iii }}$

In the premodern period, the Sanskrit word lāvanya was also used as the synonym for the term 'beauty' by Anandavardhana in Dhvanyāloka. (Anandavardhana and Abhinavagutpta, 1990, p. 184) The other words like ramya, ramaṇiya, vāma, camatkrtti, were also in use as synonyms for beauty, in other literary texts.

In common practice, the Sanskrit word saundarya refers to the 'state of being beautiful.' The $2 \mathrm{o}^{\text {th }}$ century scholars and poets ascribe a meaning to the word saundarya that captures an aesthetic judgment (Shivarudrappa, 2011, p. 47). It is used as an adjectival phrase and therefore falls into the aesthetic register. This meaning has been reinforced through its use in modern literature in India to stand in for an aesthetic equivalent though its original meaning might have referred to only an experience. For instance, saundarya is used as a word to translate the English word 'aesthetics' in the languages like Kannada. iv Shivarudrappa, in his book (2011), traces the history and the etymology of the word saundarya to estabilsh its aesthetic origins. As he (2011, p. 50) argues, the word saundarya derives from the root word sund which means 'illuminate'. He suggests that to be considered beautiful, an object should have such characteristics which give a kind of illumination or a kind of pleasing quality to it (Shivarudrappa, 2011, p. 50). Currently, we can consider beauty in its experiential meaning that is closer to its usage in premodern traditions. A conceptual study of beauty can further clarify for us if it is indeed not a mere experience, but something more.

This understanding of the word sundara foregrounds the objective nature of beauty. On the other hand, if we posit that our mind has certain qualities which make the object look beautiful, then the experience of beauty becomes subjective. Therefore, the question is whether beauty is in the "eye of the beholder" or is it inherent as a quality in the object? 
Here, we can say that the experience of beauty is neither purely subjective nor purely objective, but it is the co-constitutive of both. I claim that the notion of imagination, as one of the functions of mind in harmony with the quality of beauty in the object may make the aesthetic object look beautiful for the subject. I suggest that this kind of imagination is triggered by the perception of the object's form and content. As the image of the object enters the mind of the subject it transforms into an image that is being recreated from the image in the memory. This transformation is the result of the process of imagination. Then the image created a sense of beauty in the mind of the subject. The harmony between the perceived object and the recreated object creates the experience of beauty for the observer, the object ${ }^{v}$ or the subject alone cannot cause this process. In this process, the image that the imagination constructs, is very subjective whereas its trigger is considered as inherent within form and content of the object. Hence, we can say that the experience of beauty is neither purely subjective nor purely objective, but it is the coconstitutive of both. This conceptualization of experience of beauty is supported by the Indian traditions of thought around perception and inference (anumāna) that will be discussed in detail in a later section. Let us further examine the idea of beauty and its implications for aesthetic theories.

Aurobindo's (1997, p. 145) classifies beauty into four types - sensuous beauty, intellectual beauty, imaginative beauty and ideal beauty. Among these four classifications sensuous beauty refers to the perception of beauty through senses. The beauty of nature, the twinkling of the stars, the chirping of the birds, flower blossoms, the sunset, and many other natural phenomena can be considered under the category of sensuous beauty (Shivarudrappa, 2011, p. 25). This kind of beauty can be ephemeral in nature.

What if a person considers a mathematical expression as beautiful? In this case, there is no color, no shape, no sound and no other perceptual qualities to consider as sensuous beauty. This kind of beauty, according to Aurobindo, can be considered as intellectual beauty. This is the beauty which is much related to the cognition or the intellect of a person. This gives a kind of intellectual pleasure to the person who experiences it. The last type of beauty is the beauty which is spiritual in nature. This is in keeping with the mystical tradition that emphasizes the beauty of inner world. In other words, the beauty which one can experience in praying to god, or in meditation and so on. What is interesting for us is his third category of beauty namely imaginative beauty that can be experienced through an understanding of the creative artifice.

The experience of beauty here is intensified by the act of the imagination of the poet or the producer of art by modifying the natural beauty that seems to be given. One may suggest that this act of imagination not yet an aesthetic judgment, because logical thinking or reflection has not yet occurred.

\section{Relationship Between Perception and Beauty}

All forms of beauty have to be perceived either by the mind or by the senses. Nyāya school in Indian traditions of thought ${ }^{\mathrm{vi}}$ classifies senses into eleven types. Among them five are categorized as jňănendriyas (Sense Organs), five are karmendriyas (Action Organs) and the eleventh sense is manas (mind) (Sinha, 2008, p. 17). Among five jňānendriyas (sense organs) visual perception is considered as the most predominant sense. Eventually, all data which are collected directly from these five jňānendriyas are considered as pratyakșa (direct perception). For most schools in Indian traditions of thought, this sense perception (i.e. pratyakșa) is one of the primary sources of knowledge (Velasquez 2009, p. 303). This suggests that the perception of beautiful objects, 
according to Indian traditions of thought, primarily occurs through senses. This doesn't mean that every perception we have perceived through the senses is beautiful. What differentiates the object or the sense which we sense as beautiful from the unbeautiful ones?

Bhattacharya (2011) discusses the concept of 'beautiful and ugly' and also the role of subject in the experience of these two characteristics of objects that are called beautiful. The fundamental point that he (2011, p. 202) makes is that it is the mental attitude (feeling) which helps the subject to experience aesthetics and analysis of this, and it cannot be intellectual. While interpreting the characteristic nature of the experience of beauty and ugliness Bhattacharya (2011, p. 203) notes

If the feeling of identity be called enjoyment, the feeling of difference may be taken as a pain, both the feelings being on the artistic or contemplative level. Now enjoyment and pain cannot simply stand together side by side: one is subordinated to the other, subordination being a unique relation in the sphere of feeling. When the pain is subordinate to the enjoyment, we have the feeling of beauty. Where the enjoyment is subordinate to pain, there emerges the feeling of ugliness and its congeners.

This feeling of pain, according to Bhattacharya, is not explicitly felt in the case of primary feelings. Further, he notes how the dominant positions of these two feelings - feeling of pleasure (or enjoyment) and feeling of pain - determine the experience of pain or enjoyment by the subject.

Battacharya's claim that there is no intellectual involvement in aesthetic judgment, is not very appropriate for the discussion of beauty in everyday objects. But one can find the active and conscious involvement of intellect in the case of symbolic experience. Besides, the category of feeling is not confined to just the qualities of the objects, but maybe influenced by other conditions of life. In such cases a theory of aesthetic becomes reduced to the explanation provided by psychological studies. This, then leaves no room for cognitive theories of art or literary appreciation. If we consider this Bhattacharya's explanation only for understanding the experience of pleasure or pain, it makes sense. But I posit that after this experience of pain and pleasure, a certain intellectual endeavour also occurs that allows for aesthetic judgment.

The different cultures have different qualities that they expect the objects to possess that give pleasure. Therefore, in most cases, the understanding of that particular culture is required to attain the experience of beauty in everyday objects, such as the order of objects in a ritual performance. Take for instance, the application of cow dung on the walls of huts and houses in rural India. This is considered as a craft and the surface preparation by the women is considered to be beautiful. At the same time for people from other cultures cow dung plastering on the wall may seem disgusting.

This claim can be made in the case of arts and artistic outcomes as well. Some paintings can be really pleasing. But there can be some paintings which may not please the viewer. The problem I would point out here is the problem of making only judgment between binaries. If a painting is not pleasing, then it doesn't mean that the painting is unbeautiful. For example, suppose a person finds a painting unbeautiful it may be caused by many conditions. Firstly, the perceiver who cannot perceive colors, cannot experience the beauty of a painting which is filled with colors. Secondly, she may attribute the idea of 'unbeautiful' to the painting thus not be triggered by it to experience pleasure. To understand this from indigenous experience point of view, we can also think that the person doesn't have any indigenous understanding of the painting. For example, in the case of Chittara Art ${ }^{\mathrm{vii}}$, one certainly needs to have the context-based 
understanding to appreciate that painting. In other words, the background of the painting and the meaning that is created by the artist through painting is much necessary to know in order to appreciate that painting. Otherwise, the painting may merely provide the aesthetic experience of visual pattern. One cannot attain the symbolic experience of the art presented to us. In all these cases, the experience of beauty becomes dependent on the perceiver. This may lead to the idea of relative beauty and particularity of judgment. The judgment here also be permeated with the community involvement. A person, even though she may not be acquainted with certain symbolic meanings, the involvement with other people in that particular community, in which the everyday object or the art form is used, may help her to appreciate the object, both aesthetically and symbolically. To understand this involvement of community one certainly needs to look at the concepts of sahrdayatva and intersubjectivity.

\section{Intersubjectivity and Empathy}

In the case of the experience of both symbolic as well as visual triggers, we can claim that there is need of another element which connects the viewers of a culture who have an aesthetic experience. In Indian theory of aesthetics this element is discussed as sahrdayatva (the state of empathetic response). This concept of sahrdayatva creates sahrdaya or prekșaka (an ideal audience). In the text Nātyaśāstra, in $27^{\text {th }}$ chapter, $55^{\text {th }}$ verse, Bharata defines prekṣaka:

He who experiences happiness in happiness, and sorrow in sorrow,

experiences pity in the pitiable, is called as prekșaka in the nātya.

The verse also hints at another concept called empathy. In other words, while listing out the characteristics of an ideal audience one can note that the person should have the quality to empathize with the emotions of the character and respond accordingly. It is this state of empathetic response which sets up a stage in which every individual member of audience comes together and share a commonality. This stage can be called as intersubjectivity. Kant defines the term intersubjective as "that which is constituted by the intersubjective interactions (Gardner 2003, p. 280)". But for Husserl, intersubjectivity/ intersubjective experience allows one to constitute oneself both as "objectively existing subjects, other experiencing subjects, and the objective spatio-temporal world" (Beyer, 2003). It is, therefore, an experience which is constituted in the process of empathy, according to Beyer (2003). The concept of intersubjectivity, according to Husserl, takes place when one attributes one's own actions to other subjects. This intersubjectivity is a crucial factor which helps the audience in experiencing rasa in a performance according to Indian aesthetic theories. At this juncture, since every individual members of audience share the common ground, it creates a kind of community. Therefore, the idea to serve the quality of empathy is the most fundamental criterion in aesthetic experience.

In the case of the appreciation of Rangoli, one can extend these concepts into a more general idea of aesthetics. For example, if a person doesn't know the symbolic meaning and patterns of Rangoli, or the significance of Rangoli, through involvement with the community in which the Rangoli was drawn, he or she learns how to appreciate it. Furthermore, the person who belongs to the same community also learns different possibilities of drawing different patterns using same dots. Thus, this involvement with a cultural community helps the people to either learn or explore the different possibilities of experiencing the objects that are used in even in everyday life and extend their aesthetic appreciation to the symbol rather than just the perceptual level. 


\section{Imagination and Aesthetic Judgment}

We can thus posit that aesthetic judgment must also be a result of a cognitive process because it is symbolic. Two of the significant faculties of mind that are involved in judgment are imagination and understanding.

First let us examine the process of imagination itself from Indian Philosophy. When a person's mood is receptive along with the function of imagination, the suggestion of pleasure creates an aesthetic experience. Such an imagination helps to infer the judgment of beauty only when the person is in a receptive mood. Indian traditions of thought consider this receptive mood as that which helps in Bhāvayitrī Pratibhā (receptive imagination). ${ }^{\text {viii }}$ The Sanskrit term pratibhā is used to describe the concept of imagination. In one of the earlier references, Bhatța Tota in his opus, Kāvya Kautuka (Shreekantaiyya 2001, p. 34), defines pratibhā as the consciousness (prajňa that has the ability to help to flash newer things in the mind. Later, Rãjaśekhara in his Kāvyamìmāmsa classifies pratibhā (imagination) into two types - Bhāvayitrī (Receptive Imagination) and Kārayitrī (Creative Imagination). Bhāvayitrī Pratibhā, according to him, is a kind of imagination of the receptor. This imagination of the receptor functions parallel to the imagination of the poet. ${ }^{\text {ix }}$ Kärayitrī Pratibhā or creative imagination is that which helps in creating an artwork or an art performance. The cognitive capacity which, thus, helps one in seeing new dimension or a new meaning can be considered as imagination that helps us to experience aesthetic pleasure.

On the other hand, Coleridge classifies imagination into two types - primary imagination and secondary imagination. He considers primary imagination as "a finite repetition of creation, whereas the secondary imagination is an echo of the primary; that it dissolves to recreate or, at least, 'to idealize and to unify"' (Richards 1934, p. 72).

How does imagination help in creating symbolic association from memory? Considering both views discussed above, we can conclude that the account that the experience of sensuous beauty seems to be followed by the direct perception, whereas the imaginative beauty is based on the inference (anumāna). The major reason for this claim may be the fact that imagination gives pleasure in the case of imaginative beauty and the process of imagination seems to infer something as associated with something. For example, in the case of Rangoli, the spectator sees the Sees the Rangoli not merely as a beautiful pattern Here the characteristics of painting such as color, shape, structure, symmetry and so on help her in the process of imagination. We can perhaps say that the experience of imaginative beauty therefore needs inference (anumana) that connects the experience of pleasure to the presence to certain criteria (properties of the qualities of the object) say the religious or sacred significance of the particular pattern used. Therefore, inference (anumāna) can be one of the major constituents of aesthetic experience of everyday objects.

We can suggest that imaginative judgment fundamentally relies on this notion of associative inference. For example, to judge whether a rose is beautiful or not, one gathers all the perceptual data from the rose such as color, the intensity of the color, the shape, the fragrance and so on. Based on the sense datum, the person is able to judge whether the rose is beautiful or not through the process of her receptive imagination that connects memory, experience and knowledge of the qualities of the objects. 


\section{Aesthetics in Everyday Objects}

While it is easy to understand aesthetic judgment of available aesthetic objects such as art, theatre performances, or music, it is harder to understand the aesthetic of everyday objects ${ }^{\mathrm{x}}$. For example, the aesthetics of food preparation and serving, the beauty of everyday functional objects such as knives, or kettles, can also be considered under the general category of aesthetic objects. Leddy (1995, pp. 259-268) describes some of the terms that are associated with the notion of aesthetics in everyday life. He says the terms like neat, messy, dirty, sloppy and order and so on are the words which are often used and are related to the realm of aesthetics (Leddy 1995, p. 259). The common thread behind these terms suggests that the objects in quotidian life have to be clean and ordered for them to be beautiful. Leddy (1995, p. 262) also quotes Göran Hermeren on different qualities of aesthetics. They are - emotional qualities, behavioral qualities, gestalt qualities, taste qualities and affective qualities. Leddy (1995, p. 262) posits that gestalt qualities can be applicable in the case of everyday aesthetics. That is, the qualities such as coherent, neat, simple, balanced, harmonious, chaotic, and integrated and so on, which form the background to everyday life provide pleasure to the viewer. In his arguments, he points out the aesthetic theories which discuss art forms are different from those that can discuss the aesthetics of everyday life. In this section I draw from this Leddy's work and earlier sections on beauty and imagination to suggest that imagination can play a role in making any object into an object that elicits aesthetic judgment.

Ordinary objects on their own are not considered as aesthetic objects. The explanation for neglecting aesthetics in everyday objects is that the aesthetic experience is often explained as a transcendental experience (Leddy 1995, p. 262). Since the objects which are used in quotidian life endeavours cannot surpass the artistic objects in providing aesthetic experience, people often marginalize the experience of beauty that they have in daily life, he $(1995,264)$ claims. He also claims that the words which are mentioned above - neat, clean, messy, simple, balanced, and so on - can be considered as aesthetic properties of everyday objects (Leddy 1995, p. 267). These characteristics together add to the beauty of the object in totality. The problem is that we cannot isolate these characteristics and argue that any one of the them mentioned above, singularly cause the experience of beauty in the case of everyday objects. In many cases the synchronization of two or more characteristics would make the objects seem beautiful. For instance, the shape and the symmetry of the objects could also be the characteristics that evoke the experience of beauty in everyday objects. Wittgenstein notes:

Suppose you are fitting a door in a wall and marking out the place for the frame. You will step back from time and ask yourself: does that look right? This is a real question but it is not a question that can be answered in functional or utilitarian terms. The doorframe may be just what is needed for the traffic to pass through, it may comply with all requirements of health and safety, but it may simply not look right (Dowling 2010, p. 225).

The quotation by Wittgenstein suggests two major elements - symmetry, and purpose are inherent in everyday objects. The very idea behind fitting a door is to provide space for the people to walk in or out of the house safely. How does correction of frame matter in terms of the intention? The other purpose behind the correction of the frame is to make it look aesthetically beautiful. Even though the sense of beauty here in this case is not very directly related to the primary intention, it is to avoid the door to look 'not beautiful'. This may be related to the idea of symmetry. 
Sarukkai (2004, pp. 105-106) in his book argues that symmetry can be based on perception. He notes that the imagination sometimes fills up the blanks in perception. For example, if a person sees a half of the bus, she imagines the rest half and gets the knowledge that it is a bus. In this case, the latter half is imagined through the help of the perception of the former half. This imagination triggers the idea of symmetry. This symmetry further adds up to the experience of beauty and aesthetics. Thus, the idea of beauty involves order, shape, symmetry and arrangement of objects in everyday life. Thus, we can suggest that in Indian cultural context we certainly need to understand the symbolic meaning of the object in order to appreciate the aesthetics of it. This idea could be refuted in the western context, because for the West, to appreciate any art object or any art form the perceiver doesn't need to necessarily understand the meaning. But in India, especially in the context of ritual actions, and in the appreciation of everyday object, the symbolic meaning adds to the complete aesthetic appreciation. Therefore, in ritual performances, especially in India, one can observe the importance given to the order of the object and the decorum of the performance that requires performance without changing the prescribed ritual order. Along with the symbolic meaning there is certainly need of other aesthetic qualities such as symmetry, shape, color and so on, and the appreciator should also be able to use as an aid for imagination.

Let us now discuss the concept of beauty with respect to the objects and endeavours of everyday life in cultures such as tribal community or folk artists. For this I consider two examples from two different existences. Firstly, the case of Rangoli art.

Secondly, the art of the people of in the everyday life of Khoai community studied during a short field visit to Santiniketan, a place in West Bengal. This example is particularly chosen to discuss the purview of aesthetics that can be extended to the realm of everyday objects - i.e. arrangement of such objects, the philosophy behind the use of those objects, and the coconstitution of aesthetics through the usage of such objects and so on. This example also marks the difference between aesthetic experience and indigenous experience. These two examples attempt to theorize the concept of aesthetics in indigenous experiences in the life of people, especially, in the second example, in the life of Khoai community.

In the case of Rangoli, the cultural purpose of drawing the Rangoli merges with the presentation of it. While the most basic Rangoli can be a simple line drawing in white rice powder, it begins to also manifest as a complex folk-art form in some instances. To draw Rangoli, people use different colors and different materials to make it look beautiful. Though it is a part of a cultural practice, it serves the purpose of decorating the house because of the variety in color, shape and the creativity in drawing the patterns. There are several shapes and pictures that are drawn based on context, events in the house, season, and festivities. But generally, in the everyday practice, the pattern and the lines in Rangoli are considered aesthetically beautiful only when there is an underlying symmetry in those patterns and lines. ${ }^{\mathrm{xi}}$ Thus, the idea of symmetry functions vital role in everyday aesthetics.

Moreover, the art of Rangoli is symbolically significant as well. In many cultures it serves the purpose of revealing certain meanings. For example, if the Rangoli art form consists of an image of a snake and its hood, it means that the house is celebrating Nagara Panchami festival. If there is no Rangoli art in front of the house, it symbolically suggests that some family member in that house is passed away. Likewise, there are many symbolic meanings embedded in this art form. In the same way one can also look at the symbolic meaning in many everyday actions. These symbolic meanings also help the person to appreciate aesthetics of the objects or the everyday actions. 
The second example I consider is the paintings and murals on the walls of houses of the Khoai tribal community and the paintings of Niharika Art Gallery (henceforth NAG) ${ }^{\mathrm{xii}}$ in Santiniketan, and the curation of tribal houses in Srijani Shilpa Graam (henceforth SSG). ${ }^{\text {xiii }}$ The paintings on the walls of the houses of Khoai community, the paintings at NAG, and the daily utensils, the musical instruments, the clothes and the agricultural equipment, and the arrangement of these objects function as a display of that culture. One could say the visitors looking at these objects have some kind of aesthetic experience, yet we can say that the Khoai would also appreciate and enjoy those objects in their own lives, perhaps even if they are not curated and put on display in their homes. Thus, the question one may ask further is about the aspect of the object that causes aesthetic pleasure in both the cases. What are the necessary and sufficient conditions to make an object look aesthetically pleasing? What is the role of form and content in constituting aesthetic beauty in the object? Will these conditions turn any object into an art object? The purpose of the object also plays very paramount role here. That is, the purpose behind the paintings and murals on the wall can include a ritualistic purpose, that is those paintings may be the part of some rituals. For example, in the southern part of India, majorly in Karnataka, during the marriage rituals we can observe the names of the couple who are getting married, on the walls the house where the marriage is located within some other art paintings that frames or adjoins it. In some cases, Chittara Art can be seen on the walls and in some other cases they are the paintings of a couple or some other objects. The major categorical difference here is that, in the case of paintings and murals on the Khoai community houses and SSG houses are considered as the part of daily life whereas the paintings at NAG or the Chittara Art are considered as art form. The major idea of place and temporality also differentiates these two categories. That is, in the case of NAG, it is exhibited in a closed house where that particular place is not a part of anybody's life. Whereas in the case of the Khoai houses and the SSG houses, the paintings are the part of their everyday life. They serve some purpose in the lives of Khoai people and the other community people in the case of SSG houses. That is the paintings and murals somehow increase the beauty of their houses and at the same time they may be the part of their ritual life as well. In the case of NAG, they don't take part of any ritual life, they are purposeless, except for their aesthetic value. In the NAG, somehow place and placement becomes important whereas in the Khoai houses, paintings become important. Hence, I would suggest that, in the case of aesthetics of quotidian life, the temporality of objects is not suspended. However, in the NAG, the objects are curated in place and time. John Dewey notes:

When artistic objects are separated from both conditions of origin and operation in experience, a wall is built around them that renders almost opaque their general significance, with which esthetic theory deals (Dewey 2005, p. 2).

Hence, this priority of place over the paintings and the paintings over the place, and the purpose will mere solve the categorical issue of an art and non-art object. But the commonality one may find in these both cases lies in the imagination behind these paintings. This imagination behind painting and murals somehow communicates the purpose of the painting in some cases, and it may trigger the spectator to exercise her own imagination in one or the other direction. This idea of imagination will result in having aesthetic experience. There may be only degrees of aesthetic difference in the way this imagination operates for the art appreciator and the Khoai tribal. In other words, whenever one sees the paintings and murals on the walls of SSG and Khoai tribal houses, the perception creates a context and thus understanding which later has a harmonious interplay with imagination. This interplay co-constitutes the experience of aesthetics. Here the understanding is possible through the empathetic perception of the mural or the painting. The 
empathy which arises in the mind of the observer constitutes the intersubjectivity. Therefore, one can posit that the imagination with intersubjectivity enhances the aesthetic experience.

\section{Purpose as the aesthetic quality}

To conclude, therefore, it seems that the objects or the actions in quotidian life carry two major characteristics which draw our attention towards these objects - purpose and beauty. Here the purpose involves both the usefulness of the object or the action and the symbolic meaning attached to it. The experience of beauty occurs through the pleasure of inferring the qualities of that Leddy refers to, such as neatness, messy, etc. However, the purpose is also an important aspect of these everyday objects. Perhaps the value one gives to the characteristic of beauty is always more than the values that one gives to the purpose. The process of choosing objects in everyday life like choosing clothes, furniture, cutlery, water bottles, and so on involves the values one gives to the characteristic of beauty in every object along with the efficiency of its primary purpose. Therefore, the duality between beauty and purposiveness is merged in the case of everyday aesthetics.

We find that the aesthetics of everyday objects requires us to rethink the notions of beauty, pleasure, imagination, inference (reason), and senses. While dominant theories of aesthetics help us to understand the obvious aesthetic objects like art, theatre performances and so on, alternative ways of understanding aesthetics are needed to unpack these ideas for other experiences of beauty.

\section{Endnotes}

${ }^{\mathrm{i}}$ Rangoli is also known by different names in different parts of India. Kolam in Tamil Nadu, Alpana in Bengal, Magga in Telangana, Rangavalli in Sanskrit, wherein Rajasthan it is called as Mandana. For more see ("Kolams", n.d.).

${ }^{\text {ii }}$ Amarakośa is a Sanskrit thesaurus by the Sanskrit scholar called Amarasimha. There is a debate in terms of the period of the text in which it was written. Some scholars note that it has been written in circa $5^{\text {th }}$ Century CE, some other scholars say it is written in circa $7{ }^{\text {th }}$ Century CE.

iii It doesn't seem to define any meaning to the words like manoramam and sușamam. But Monier Williams's dictionary defines manoramam as gratifying the mind, attractive, pleasant, charming, and susamam as splendid, very beautiful, and intelligible and so on. For more see (Williams 1899).

${ }^{\text {iv }}$ Swamy $(2003,9)$ notes that the grammarians would use the word alamkāra as synonym for beauty. Hence, they named their school after it as Alamkāraśāstra.

${ }^{v}$ Mental objects such as memories of beautiful things or mathematical expressions may not strictly be outside the mind, but they are the objects of beauty, in the sense that they are passive for the gaze of subject.

${ }^{\text {vi }}$ Phenomenology explores the idea of experience and is a dominant theoretical framework for this kind of analysis. Here the purpose is to use a different register from a different culture to seek for alternative modes of explanation. 
vii Chittara Art (also called as hasegode and hasechittara) is an indigenous art which is mostly prevalent in Karnataka state. In this folk-art form, artists mostly use red soil to create color for background of the painting and use the liquidated form of white soil or rice paste, to produce white paint, burnt rice to produce black paint and yellow seeds to produce yellow color. For more see (Chittara Art 2019).

viii The idea of imagination and aesthetics is drawn from both literary and performative traditions in Indian traditions of thought. Particularly scholars of premodern posit that there is a form of Indian aesthetic theory based on these concepts. For instance, see (Shulman 2012).

${ }^{\text {ix }}$ For more information see (Parashara 2013, p. 48).

${ }^{x}$ Leddy and Saito in their works use the term 'everyday aesthetics' and they describe the characteristics of everyday aesthetics. For more see (Leddy 1995 \& Saito 2008).

${ }^{x i}$ Modern Rangoli artists tend to create images and pictures on the ground with colored powder, this is not considered as a traditional Rangoli.

xii The Niharika Art Gallery consists of the paintings of Prof. Selim Munshi, renowned artist from West Bengal. This gallery is located in Santiniketan where it is opened to the visitors. For more details see ("Selim Munshi", n.d.).

xiii The tribal community called Khoai is located near Santiniketan, West Bengal. Author has visited this place on 16 and 17 December 2015 and interviewed many people in the premise of Santiniketan. The Srijani Shilpa Grama is a museum kind of place in the campus of Santiniketan where the attempt is to bring the houses and recreate them as they were in their original place, from different states of India. Hence this paper will source many examples from the visit.

\section{References}

Amarasimha. (2013). Amarakoṣah, Pandit Shivadatta, (Ed.), Varanasi: Chowkhamba Krishnadas Academy.

Anandavardhana., \& Abhinavagutpta. (1990). The dhvanyaloka of anandavardhana with the locana of abhinavagupta, Daniel H Ingal (Trans.), London: Harward University Press.

Aurobindo. (1997). The complete works of sri Aurobindo, Vol. 26: The future poetry, Pondicherry: Sri Aurobindo Ashram Publication Department.

Beyer, C. (2003, February 28). Edmund Husserl. Retrieved April 21, 2018, from https://plato.stanford.edu/archives/win2016/entries/husserl

Bhattacharya, K. C. (2011). The concept of rasa, In N. Bhushan \& J.L. Garfield (Eds.), Indian philosophy in english (pp.193-206). New York: Oxford University Press.

Chittara Art. (n.d.). Retrieved May 30, 2019, from http://indianfolkarts.com/Admin/Transactions/FormsOfArt/Pages/Forms-Of-Art17.aspx

Dewey, J. (2005) Art as experience, New York: Penguin Group.

Dowling, C. (2010). The aesthetics of daily life. British journal of aesthetics Vol. 50(3), 225-242.

Gardner, S. (2003). Routledge philosophy guidebook to kant and the critique of pure reason, London: Routledge. 
Kolams. (n.d.). Retrieved December 07, 2017, from http://www.indianheritage.org/alangaram/kolams/kolams.htm

Leddy, T. (1995). Everyday surface aesthetic qualities: "neat," "messy," "clean," "dirty". The journal of aesthetics and art criticism 53 (3), 259-268.

manorama; susama. (1899). In Monier-Williams Sanskrit-English Dictionary, 1899. Retrieved January 24, 2017, from http://www.sanskrit-lexicon.unikoeln.de/scans/MWScan/2014/web/webtc/indexcaller.php

Parashara, S. (2013). Kāvyamīmāmsāa of rajashekhara. New Delhi: Neha Publishers \& Distributors.

Richards, I. A. (1934). Coleridge on imagination, London: Kegan Paul.

Saito, Y. (2008). Everyday aesthetics, New York: Oxford University Press.

Sarukkai, S. (2004). Philosophy of symmetry, Shimla: IAAS.

Selim Munshi. (n.d.). Retrieved May 31, 2016, from https://sites.google.com/site/selimmunshi/

Shivarudrappa, G. S. (2011). Saundarya sameekshe [A glance of beauty]. Bangalore: Kamadhenu Pustaka Bhavan.

Shreekantaiyya, T.N. (2001). Indian poetics, N. Balasubrahmanya (Trans.), New Delhi: Sahitya Akademi.

Shulman, D. (2012). More than real: A history of the imagination in south india, London: Harvard University Press.

Sinha, J. (2008). Indian psychology, vol.1: Cognition. Delhi: Motilal Banarsidass Publishers Private Limited.

sumdara; rucira; caru; sadhu; zobhana; kāntam;; rucya; mamju; mamjula. (189o). In Apte Practical SanskritEnglish Dictionary, 1890. Retrieved January 24, 2017, from http://www.sanskrit-lexicon.unikoeln.de/scans/AP9oScan/2014/web/webtc/indexcaller.php.

Swamy, M. S. (2003). Saundaryam alanikārah. In V. N. Jha (Ed.), Indian aesthetics and poetics (pp. 8-22). Delhi: Sri Satguru Publications.

Velasquez, M. (2009). Philosophy: A text with reading. Wadsworth: Cengage Learning. 